\title{
Response to Owen, H.G. (2014), Discussion on “Aldiss, D., Under representation of faults on geological maps of the London region: reasons, consequences and solutions.” [Proc. Geol. Assoc. 124 (2013) 929-945].
}

I thank Dr Owen for his comments on my paper (Aldiss, 2013) and for his useful exploration of several aspects of the tectonic development of the London region. I am especially grateful for him drawing attention to his evidence for Quaternary faulting of the Gault in the south London area, and to several other pertinent and useful papers, notably Lake’s (1975) discussion of the tectonics of the Weald and those by Owen (1971, 2012). However, I feel that his remarks mainly concern topics that are beyond the scope of my paper.

My paper was not about the 'distribution of current faults in the London region', as much as being about the current understanding of the distribution of faults in the London region. I was not attempting to demonstrate that the London region has, in reality, been tectonically inactive nor that no faults have been recognised in the area - only that faulting is greatly under-represented on the local geological maps.

In introducing this topic briefly, it appears that I have perhaps described the tectonic development of the region in an over-simplified manner. Also, it would have been useful to emphasize the distinction, within the term 'tectonic activity', between regional crustal uplift and subsidence (which may or may not be accompanied by faulting, and which is not directly relevant to the main subject of the paper) and fault displacement, either vertical or lateral. However, my principal point remains the same: few faults are shown on geological maps of the London area and this is both a consequence of and a contributory cause of a perception that the London Platform is an area of long-term relative crustal stability, compared with the Weald Basin.

In this respect, the existence (or not, as suggested by Owen, 2014) of a Variscan fold belt beneath the Weald Basin is beside the point, as is the existence, position and nature of a 'Variscan Front'. Without wishing to explore these interesting topics in detail in this correspondence (as Owen notes, it is a subject on which even some co-authors cannot agree), on the former matter I find it difficult to see how the Variscan fold belts observed in the west of England and South Wales, and in Belgium and northern France, do not continue along strike beneath the Weald. Moreover, the absence of Silesian strata from southern England suggests that the region experienced extensive late Palaeozoic uplift relative to east Kent and Berkshire, where there are thick Westphalian sequences. Reactivation of Variscan thrusts within this area is thought to have led to the development of syn-sedimentary growth faults during the development of the Weald Basin, which were in turn reactivated when that Basin was uplifted, leading to the formation of high-angle structures in the vicinity of the North Downs near London (Smith, 1985; Whittaker, 1985; Chadwick, 1986, 1993).

I believe that the 'Variscan Front' is a useful concept to describe the northern limit of Variscan thin-skinned tectonics, as proposed by Shackleton (1984) who accepted that some Variscan deformation, including faulting, extends to the north of that limit. As such, it seems likely that the Variscan Front could be offset along axes such as that represented by the Wheatley Fault or, indeed, the Greenwich Fault. As pointed out by Owen, Lake (1975, fig. 1) suggests that the Variscan Front (as then understood) could be as far south as a line between Dorking and Biddenden. Lake did not, however, have the benefit of modern regional gravity anomaly maps, which show a similar pattern of Bouguer anomalies throughout the Weald, at 
least as far north as the Lower Greensand escarpment on the northern fringe of the Weald (Aldiss, 2013, fig. 11). Indeed, Busby and Smith (2001) show from an analysis of geophysical data that it is at least plausible that the gravity low under south London also marks part of a Variscan fold belt (Aldiss et al., 2014, fig. 2).

Owen takes issue with my assertion that 'older Mesozoic strata were never deposited [on the London Platform], or were subsequently largely eroded'. While this abbreviated statement may not be very informative, I believe that it accurately summarizes Owen's more detailed descriptions, as given in his discussion and in the papers that he cites.

In his discussion and his cited works, Owen provides evidence for extensive faulting in the London Region, both in the basement and within Mesozoic formations. He (Owen, 1971, p. 205) states 'it appears, however, that the [southern margin of the London Platform] may have a pre-Cretaceous tectonic history as complex as that of the Boulonnais', and I am inclined to accept this. However, there appear to be very few, if any, instances where he has shown the traces of corresponding faults at the surface, or at rockhead, other than on the outcrop of the Lower Cretaceous formations. This illustrates one of the difficulties of mapping (or modelling) faults in the London region: faults that displace concealed Lower Cretaceous or older strata do not necessarily extend up into the Chalk, let alone up to rockhead in the Palaeogene formations.

Indeed, at the present stage of research in the London region, it seems more useful to infer the presence of faulting at or near the surface (for example by the use of detailed 3D geological modelling such as by Aldiss et al., 2012) where, in the nature of things, there is generally more information with which to identify faults and to constrain their position, and then project the modelled lines of faulting downwards as a guide to the position of inferred faults in the older formations. This approach would also better serve the needs of the engineering sector, whose immediate interests lie in the zone of human interaction, rather than in formations concealed beneath the Chalk. An example is provided by the NNW-SSE fault bounding the west side of Kent coalfield shown by Owen (2014, fig. 1; 2012, fig.1). Although this interpretation is attributed by Owen (2014) to Lake (1975), Lake's figure 1 shows a questioned north-south line of faulting - presumably placed in a more-or-less arbitrary position for lack of evidence - on the west side of the coalfield, following ShephardThorn et al. (1972). More recent geological mapping in east Kent inferred the existence of some NNW-SSE faults in that area (Aldiss, 2013, fig. 4b), substantiating the interpretation given by Owen, but also found extensive NE-SW faulting, suggesting that faulting on that trend would also be expected to be present in the Palaeozoic basement in that area, and might play some part in determining the extent of the coalfield.

\section{Acknowledgements}

I thank Nigel Smith for helpful discussions at various times regarding the pre-Mesozoic basement of southern England.

This discussion is published with the permission of the Executive Director, BGS (NERC).

\section{References}


Aldiss, D.T., 2013. Under-representation of faults on geological maps of the London region: reasons, consequences and solutions. Proceedings of the Geologists' Association 124, 929945.

Aldiss, D.T., Black, M.G., Entwisle, D.C., Page, D.P., Terrington, R.L., 2012. Benefits of a 3D geological model for major tunnelling works: an example from Farringdon, east-central London, UK. Quarterly Journal of Engineering Geology and Hydrogeology 45, 405-414.

Aldiss, D.T., Burke, H., Chacksfield, B.C., Bingley, R.M., Teferle, N., Williams, S., Blackman, D., Burren, R., Press, N., 2014. Geological interpretation of current subsidence and uplift in the London area, UK, as shown by high precision satellite-based surveying. Proceedings of the Geologists' Association 125, 1-13.

Busby, J.P., Smith, N.J.P., 2001. The nature of the Variscan basement in southeast England: evidence from integrated potential field modelling. Geological Magazine 138, 669-685.

Chadwick, R.A., 1986. Extension tectonics in the Wessex Basin, southern England. Journal of the Geological Society of London 143, 465-488.

Chadwick, R.A., 1993. Aspects of basin inversion in Southern Britain. Journal of the Geological Society of London 150, 311-322.

Lake, R.D., 1975. The structure of the Weald - a review. Proceedings of the Geologists' Association 86, 549-557.

Owen, H.G., 1971. The stratigraphy of the Gault in the Thames Estuary and its bearing on the mesozoic tectonic history of the area. Proceedings of the Geologists' Association 82, 187207.

Owen, H.G., 2012. The Gault Group (Early Cretaceous, Albian), in East Kent, S.E. England; its lithology and ammonite biozonation. Proceedings of the Geologists' Association 123, 742765.

Owen, H.G., 2014. Discussion on "Aldiss, D., Under representation of faults on geological maps of the London region: reasons, consequences and solutions.” [Proc. Geol. Assoc. 124 (2013) 929-945]. . Proceedings of the Geologists' Association.

Shackleton, R.M., 1984. Thin-skinned tectonics, basement control and the Variscan front. Geological Society, London, Special Publications 14, 125-129.

Smith, N.J.P., 1985. Pre-Permian Geology of the United Kingdom (South Sheet). British Geological Survey, Keyworth.

Whittaker, A., 1985. Atlas of onshore sedimentary basins in England and Wales. Blackie, Glasgow, pp. 1-68.

Don T Aldiss

British Geological Survey, Keyworth, Nottingham NG12 5GG, United Kingdom 
Shephard-Thorn, E R, Lake, R D and Atitullah, E A. 1972. Basement control of structures in the Mesozoic rocks in the Strait of Dover region, and its reflexion in certain features of the present land and submarine topography. Phil. Trans. R. Soc. Lond. A272, 99-113. 